\title{
A Developed Low-Cost Electrocoagulation Process for Efficient Phosphate and COD Removals from Real Urban Wastewater
}

\author{
M. Elazzouzi, ${ }^{1,2^{*}}$ K. Haboubi, ${ }^{2}$ M.S. Elyoubi ${ }^{1}$ and A. El Kasmi ${ }^{-3 *}$
}

\begin{abstract}
The treatment of urban wastewater is nowadays one of the topics taking many interests from the scientific community. This study focuses on simultaneous removal of phosphate (P) and chemical oxygen demand (COD) from real urban wastewater using developed electrocoagulation (EC) system. A comparative study of developed EC process (anode iron scrap) with a conventional EC process (anode iron plate) was performed. When developed EC process was used, the results revealed that the removals efficiencies of $\mathrm{P}$ and COD have been improved from $82 \%$ to $94 \%$ for COD and from $85 \%$ up to $97 \%$ for $\mathrm{P}$, thus led to reduce energy consumption from $7.6 \times 10^{-3}$ to $5.4 \times 10^{-3} \mathrm{kWh} / \mathrm{g} \mathrm{COD}$ and from $5.8 \times 10^{-1}$ to $4.3 \times 10^{-1} \mathrm{kWh} / \mathrm{g}$ P. The higher treatment efficiency obtained from the developed EC process can be directly attributed to the higher effective surface area of the Fe scrap. Moreover, the characterization of generated EC by-products revealed the existence of $\mathrm{P}, \mathrm{C}$ and $\mathrm{O}$ confirming that such pollutants were adsorbed on the surface of iron hydroxides and oxyhydroxides, where the removals of $\mathrm{P}$ and COD were taken place. The obtained findings could contribute to improving the EC treatment of real urban wastewater and make the treatment simple and economically feasible.
\end{abstract}

Keywords: Developed EC process; Real urban wastewater; Operating cost; Iron scrap; Sludge characteristics

Received 7 April 2019, Accepted 26 May 2019

DOI: $10.30919 / \mathrm{esee} 8 \mathrm{c} 302$

\section{Introduction}

In the urban areas, several factors such as expansion of population, increased coverage of sewerage and domestic water supply resulted in an increase in urban wastewater containing high amounts of organic, inorganic and microbial pollutants that are often responsible for the severe pollution of groundwaters, rivers and seas. ${ }^{1}$ Moreover, high phosphate concentration loading into surface water results in the eutrophication that has harmful ecological effects, including the development of oxygen-depleted and toxic algal blooms, which consequently can lead to a change in animal and plant species composition, disruption of food webs, and loss of biodiversity. ${ }^{2}$ In attempts to reduce the amount of such pollutants from urban wastewater, several methods have been investigated like coagulationflocculation, ${ }^{3,4}$ advanced oxidation processes, ${ }^{5}$ anaerobic and aerobic treatment, ${ }^{6}$ adsorption, ${ }^{7-9}$ and activated sludge. ${ }^{10}$ However, these methods are quite expensive and involve several operational requirements. For such reasons, there has been an increasing interest in the use of electrochemical methods. Moreover, electrochemical methods have several advantages such as no requirement of any chemicals before

${ }^{1}$ Laboratory of Electrochemistry and Environmental Materials, Faculty of Sciences, Kenitra, Morocco

${ }^{2}$ Group of Material Sciences, Energy and environment, ENSAH, Alhoceima, Morocco

${ }^{3}$ Institute of Engineering Thermophysics, Chinese Academy of Sciences, 100190 Beijing, China

*E-mail: achraf@iet.cn; elazzouzi89@gmail.com and/or after treatment, small operational area, producing less sludge and low-investment cost.

Recently, electrocoagulation (EC) has been applied successfully for the treatment of various types of wastewaters including textile wastewater, ${ }^{11}$ semiconductor manufacturing wastewater, ${ }^{12}$ dairy effluent, ${ }^{13}$ Groundwater, ${ }^{14}$ hydraulic fracturing wastewater, ${ }^{15}$ almond wastewater, ${ }^{16}$ oil refinery wastewater, ${ }^{17}$ tannery wastewater, ${ }^{18}$ laundry wastewater, ${ }^{19}$ river water ${ }^{20}$ and urban wastewater. ${ }^{21,22}$

In $\mathrm{EC}$, the oxidation of $\mathrm{Fe}$ anode yields the dissolution of $\mathrm{Fe}^{2+}$ in the effluent according to reaction (1) with a standard potential of $\mathrm{E}^{\circ}=$ $0.44 \mathrm{~V} / \mathrm{SHE}$, whereas $\mathrm{H}_{2}$ and $\mathrm{OH}^{-}$gases are generated at the cathode from reaction (2) with $\mathrm{E}^{\mathrm{o}}=-0.83 \mathrm{~V} / \mathrm{SHE}:^{23}$

$$
\begin{gathered}
\mathrm{Fe} \rightarrow \mathrm{Fe}^{2+}+2 \mathrm{e} \\
2 \mathrm{H}_{2} \mathrm{O}+2 \mathrm{e}^{-} \rightarrow 2 \mathrm{OH}^{-}+\mathrm{H}_{2(\mathrm{~g})}
\end{gathered}
$$

At $\mathrm{pH}>5.5, \mathrm{Fe}(\mathrm{OH})_{2}$ precipitates by reaction (3) remaining in equilibrium with $\mathrm{Fe}^{2+}$ up to $\mathrm{pH}=9.5$, or with monomeric species such as $\mathrm{Fe}(\mathrm{OH})^{+}, \mathrm{Fe}(\mathrm{OH})_{2}$ and $\mathrm{Fe}(\mathrm{OH})_{3}^{-}$at much higher $\mathrm{pH}$ values. When dissolved $\mathrm{O}_{2}$ gas presents in the medium, insoluble $\mathrm{Fe}(\mathrm{OH})_{3(\mathrm{~s})}$ can be generated from $\mathrm{Fe}^{2+}$ oxidation through reaction (4), and the release of protons can be directly reduced to $\mathrm{H}_{2}$ gas at the cathode according to reaction (5) giving the global reaction (6) in the electrolytic cell.

$$
\begin{gathered}
\mathrm{Fe}^{2+}+2 \mathrm{OH}^{-} \rightarrow \mathrm{Fe}(\mathrm{OH})_{2} \\
4 \mathrm{Fe}_{(\text {aq })}^{2+}+10 \mathrm{H}_{2} \mathrm{O}_{(\mathrm{l})}+\mathrm{O}_{2(\mathrm{~g})} \rightarrow 4 \mathrm{Fe}(\mathrm{OH})_{3(\mathrm{~s})}+8 \mathrm{H}_{(\mathrm{aq})}^{+}
\end{gathered}
$$




$$
\begin{gathered}
8 \mathrm{H}^{+}+8 \mathrm{e}^{-} \rightarrow 4 \mathrm{H}_{2(\mathrm{~g})} \\
4 \mathrm{Fe}_{(\mathrm{s})}+10 \mathrm{H}_{2} \mathrm{O}_{(\mathrm{l})}+\mathrm{O}_{2(\mathrm{~g})} \rightarrow 4 \mathrm{Fe}(\mathrm{OH})_{3(\mathrm{~s})}+4 \mathrm{H}_{2(\mathrm{~g})}
\end{gathered}
$$

The insoluble flocs of $\mathrm{Fe}(\mathrm{OH})_{3}$ remained in the wastewater solution as solid suspensions, which act as adsorbents to remove the pollutants from the wastewater by electrostatic attraction or surface complexation followed by adsorption and co-precipitation. ${ }^{24}$ Moreover, the $\mathrm{H}_{2}$ gas generated at cathode can enhance the efficiency of the separation process through electroflotation. ${ }^{25}$

Some investigations on the effect of electrode material for the treatment of wastewater using EC process revealed that employing $\mathrm{Fe}$ electrode resulted in the highest COD removal efficiency. ${ }^{26}$ Recently, another study of EC treatment process for phosphate removal from swine wastewater showed that $\mathrm{Fe}$ as anode exhibits better efficiency than aluminum. ${ }^{27}$ In despite, the usage of conventional EC processes with high-cost anode reduces the practical scope for EC application. Therefore, the use of low-cost EC anode could be an advantageous from economic and environmental sides.

It is noteworthy that only few studies have focused on the design of low-cost electrodes. For example, in the study performed by Ye et al, iron scrap was used as anode for the treatment of Ni-EDTA contained in wastewater and it was resulted in a removal efficiency of over $94.3 \%$ of $\mathrm{Ni}^{28}$ Moreover, another study conducted by Ardhan ${ }^{29}$ shows good removal of color and COD from a synthetic wastewater when low-cost iron scrap has been used as anode.

Therefore, this study aims at the optimization of $\mathrm{P}$ and COD removal from urban wastewater by applying a developed EC using lowcost anode made from waste scrap iron. To evaluate the effectiveness of this developed EC process, a comparative study with a conventional EC was performed and the effect of different process parameters such as initial $\mathrm{pH}$, current and packed anode density on $\mathrm{P}$ and COD removals have been studied. In attempts to better understand the mechanism governed the removal of $\mathrm{P}$ and $\mathrm{COD}$, the sludge formed by $\mathrm{EC}$ with iron scrap was analyzed by several techniques to reveal the structure, morphology, chemical composition and surface functional species properties of the formed sludge.

\section{Materials and methods}

\subsection{Wastewater sample and characterization}

The used urban wastewater samples in this work were taken from the wastewater treatment plant of Al-Hoceima city (northeast part of Morocco) and its principle characteristics are listed in Table 1. The samples were analyzed mainly in terms of parameters such as $\mathrm{P}$ and COD by a standard method of analysis. ${ }^{30}$ COD and P were measured by UV-vis spectrophotometer, (Spectrocoquant PHAR 300 Merck, Japan). $\mathrm{pH}$ and conductivity were measured by $(\mathrm{pH} / \mathrm{ion} /$ Cond $750 \mathrm{WTW}$ Inolab WTW, Germany). It is of interest to note that the urban wastewater was directly used here and without any pretreatment before the EC tests.

\subsection{Sludge characterization}

The sludge generated by EC was dried at $105{ }^{\circ} \mathrm{C}$ for several hours, and then powdered in mortar and pestle. The obtained powder was characterized using scanning electron microscope (SEM, Make: HIROX, FR, Model: SH 4000M), which provided the morphology of Sludge generated by electrocoagulation. Energy dispersive X-ray analysis (EDAX) is an integrated feature of a scanning electron microscope (SEM), was performed to identify the elemental composition of the sludge obtained from the electrochemical unit. X-ray diffractometer (XRD, Make: Bruker, Germany, Model: AXS D8 Advance Eco) analysis was carried out to confirm the nature (crystalline or amorphous) of the sludge and Fourier transform infrared spectroscopy (FTIR, SHIMADZU IRSpirit) was used to identify the functional groups of the sludge formed during the electrocoagulation.

\subsection{Experimental set-up for the EC process}

The developed EC process consists of scrap iron as anode and two iron plates as cathode, as shown in Fig. 1(a). The scrap iron was made from the used iron materials, which was cut into small pieces of dimension $5 \mathrm{~mm} * 5 \mathrm{~mm} * 5 \mathrm{~mm}$ then used as anode after being carefully washed. The scrap iron packed anode was constructed by filling $12 \mathrm{~g}, 24 \mathrm{~g}$ and $36 \mathrm{~g}$ of scrap iron in a cylindrical PVC perforated tube. The perforated tube has a length of $100 \mathrm{~mm}$, an internal diameter of $30 \mathrm{~mm}$, a wall thickness of $1 \mathrm{~mm}$ and a volume of $60 \mathrm{~cm}^{3}$. The PVC perforated tube contains small holes of $3 \mathrm{~mm}$ distributed on its surface to permit the transport of metal ions from the electrode. The cathode consisted of two iron plates with a dimension of $10 \times 5 \times 1 \mathrm{~cm}$. A DC power supply (ALR3002M) characterized by the ranges $0-2.5 \mathrm{~A}$ for current and 0-30 $\mathrm{V}$ for voltage was used. The distance between the two electrodes (anode and cathode) was maintained constant at a value of $2 \mathrm{~cm}$ during the electrolysis. The $\mathrm{pH}$ of the aqueous solution was adjusted using $1 \mathrm{M}$ $\mathrm{H}_{2} \mathrm{SO}_{4}$ or $1 \mathrm{M} \mathrm{NaOH}$.

Table 1 Characteristics of the urban wastewater used in this study.

\begin{tabular}{ccc}
\hline Parameters & Unit & value \\
\hline COD & $\mathrm{mg} . \mathrm{L}^{-1}$ & 1000 \\
BOD & $\mathrm{mg} . \mathrm{L}^{-1}$ & 560 \\
$\mathrm{TSS}$ & $\mathrm{mg} \cdot \mathrm{L}^{-1}$ & 450 \\
$\mathrm{P}$ & $\mathrm{mg} \cdot \mathrm{L}^{-1}$ & 12 \\
$\mathrm{NaCl}$ & $\mathrm{mg} \cdot \mathrm{L}^{-1}$ & 2.2 \\
Conductivity & $\mu \mathrm{s} . \mathrm{cm}^{-1}$ & 3200 \\
$\mathrm{pH}$ & $\mathrm{pH}$ & 7.4 \\
\hline
\end{tabular}


A batch electrochemical reactor of $500 \mathrm{ml}$ capacity with typical iron anodes was also set up for comparison. As shown in Fig. 1(b), the electrodes were connected as anode-cathode-anode-cathode in the monopolar mode, installed in parallel and immersed up to $6 \mathrm{~cm}$ in depth. Each electrode has a dimension of $10 \times 5 \times 1 \mathrm{~cm}$ with an effective area of $30 \mathrm{~cm}^{2}$. The electrode distance between anode and cathode was maintained constant at a value of $1 \mathrm{~cm}$ during electrolysis.

\section{Results and discussion}

\subsection{Effect of initial $\mathrm{pH}$}

It is commonly known that the initial $\mathrm{pH}$ is one of the most sensitive operating parameters during the electrocoagulation treatment. ${ }^{31}$ In the present study, the initial $\mathrm{pH}$ of the original urban wastewater was 7.5; and to evaluate the effect of initial $\mathrm{pH}$ on the removal efficiencies of $\mathrm{P}$ and COD using either plate iron or scrap iron in electrocoagulation processes, the $\mathrm{pH}_{\mathrm{i}}$ was adjusted. The effect of initial $\mathrm{pH}_{\mathrm{i}}$ on the removal of COD and phosphate was explored within the $\mathrm{pH}$ range of (3-9) at current of $(1.5 \mathrm{~A})$ and an operating time of $(0-10 \mathrm{~min})$. It can be observed from Figs. 2 and 3 that the removal of COD and P increased with time and the optimal initial $\mathrm{pH}$ to achieve the maximum removal efficiencies, and it was found to be 8 and $10 \mathrm{~min}$ for plate and scrap iron anode, respectively. At theses optimal conditions, the maximum COD and $\mathrm{P}$ removal efficiencies was $75 \%$ and $80 \%$ for plate anode and $80 \%, 85 \%$ for scrap anode. A slight decrease in the removal (a)

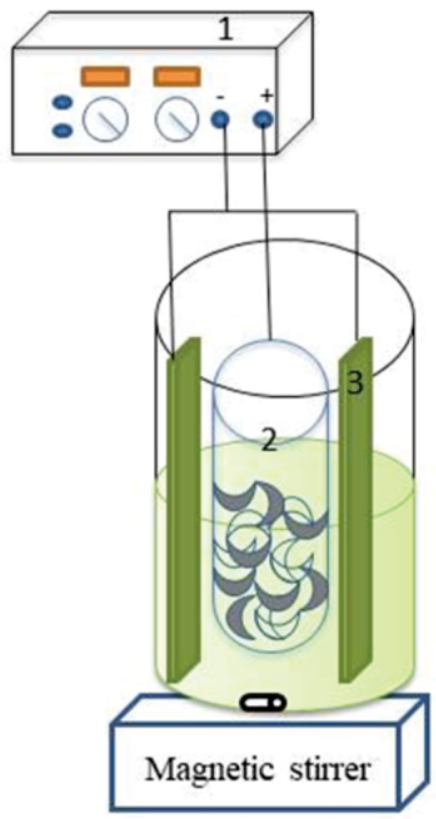

(b)

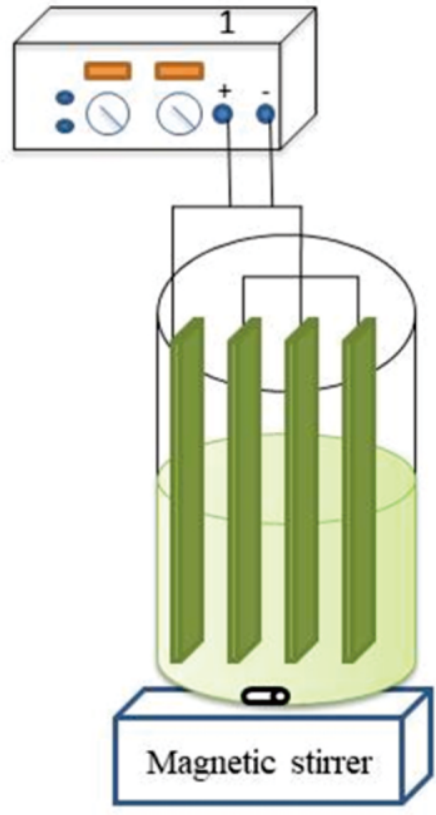

Fig. 1 Experimental setups used in this study: (a) developed EC process and (b) conventional EC process; with (1) DC power supply, (2) perforated PVC contained Fe scrap, (3) Fe plate cathode (4) Circulation pump.
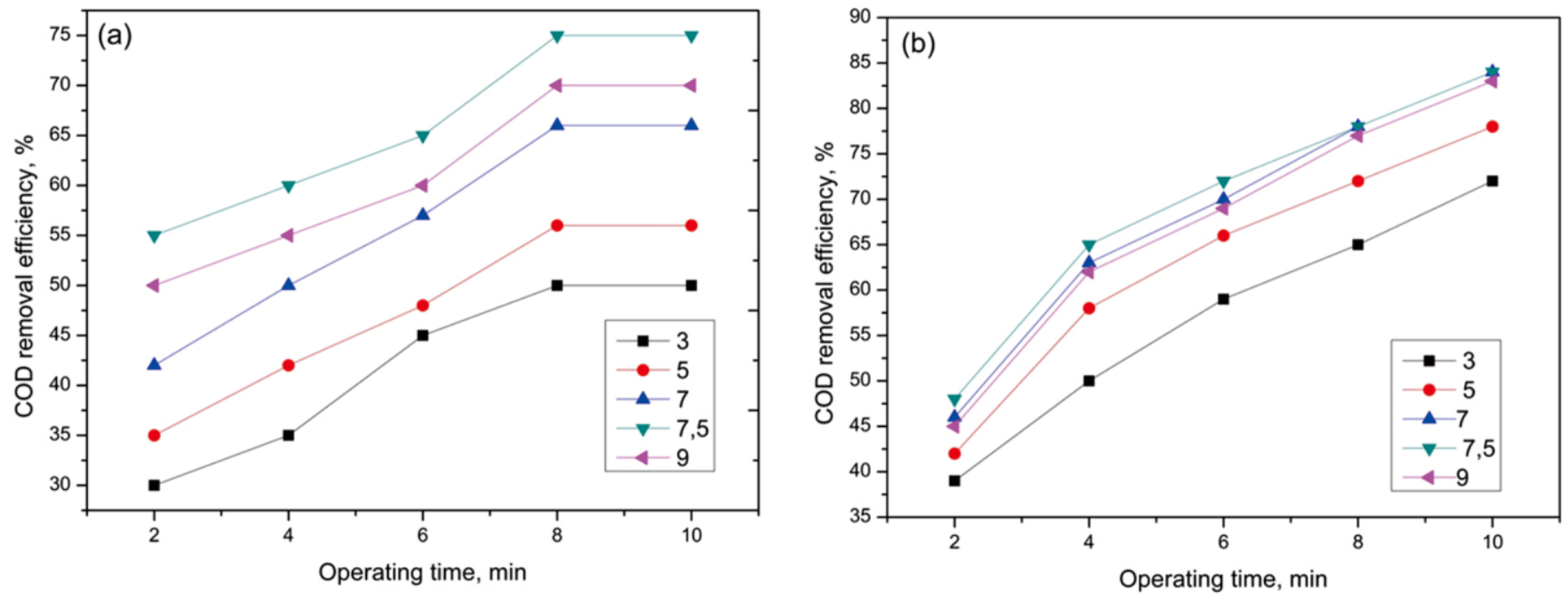

Fig. 2 Effect of initial pH on COD removal (a) Iron plate (b) Iron scrap (Current: 1.5 A; packed density 200 kg.m ${ }^{-3}$ ). 
efficiencies observed when the $\mathrm{pH}$ increased up to $7.5(\mathrm{pH}=9)$ and it decreased dramatically when the initial $\mathrm{pH}$ of solution became acidic $(\mathrm{pH}=3$ and $\mathrm{pH}=5)$. Therefore, $\mathrm{COD}$ and $\mathrm{P}$ removals at original $\mathrm{pH}$ $(\mathrm{pH}=7.5)$ were better than that at a higher $\mathrm{pH}(\mathrm{pH}>7.5)$ or lower $\mathrm{pH}$ $(\mathrm{pH}<7.5)$. As a reason of this behavior, in acidic medium solution $(\mathrm{pH}<7.5)$, the protons $\mathrm{H}^{+}$were reduced to form $\mathrm{H}_{2}$ gas at the cathode and consequently the same proportion of hydroxyl ions $(\mathrm{OH})$ could not be produced. ${ }^{32}$ In alkaline medium $(\mathrm{pH}>7.5)$, the oxidation of hydroxyl ions and the formation of $\mathrm{Fe}(\mathrm{OH})^{4-}$ and $\mathrm{Fe}(\mathrm{OH})_{6}^{3-}$ anions will take place at the anode and leading to lower the removing capacity. ${ }^{32}$ Hence, from these results we can easily conclude that there is no need to adjust the initial $\mathrm{pH}$ (7.5) of urban wastewater in order to enhance the EC performance, which is an advantage here for this study.

Fig. 4 shows that $\mathrm{pH}$ of the medium change during the $\mathrm{EC}$ process. It is of interest to note when the influent $\mathrm{pH}$ was adjusted to 3 and 5, the effluent $\mathrm{pH}$ was increased up to 6.2 and 6.8 and 6.4 to 7 for plate iron and scrap iron anode, respectively. This increase in $\mathrm{pH}$ can be explained by the occurrence of water electrolysis resulting in hydrogen evolution and production of $\mathrm{OH}^{-}$ions. However, when the influent $\mathrm{pH}$ was adjusted to $\mathrm{pH} \mathrm{9,} \mathrm{the} \mathrm{effluent} \mathrm{pH}$ was decreased to 8.4 and 8.5. It is also observed that when the influent $\mathrm{pH}$ was 7.5 , which correspond to original $\mathrm{pH}$ without any adjustment, a slight increase in effluent $\mathrm{pH}$ occurred. It is clear from these results that $\mathrm{EC}$ can be a $\mathrm{pH}$ neutralization step which provides an important advantage in its application at industrial scale.

\subsection{Effect of current}

Current has also a significant effect on the EC process, because it is a very important parameter that controls the reaction rate, production rate of coagulants, size of bubbles and growth of flocs. ${ }^{33,34}$ It is clearly observed in Figs. 5 and 6 that increasing the current led to a significant removal of $\mathrm{P}$ and COD. For example, at 8 min that corresponds to the optimal time, the increase in current from 0.5 to 2 , led to the increases in removal efficiency from 55 to $82 \%$ for COD and from 65 to $85 \%$ for $\mathrm{P}$ using iron plate anode. Similar experiments were performed using iron scrap anode, Fig. 3 (b) shows that at 10 min of operating time the removal efficiency increased from 63 to $88 \%$ for COD and from 75 to $90 \%$ for P. From these results, it can be concluded that the use of iron
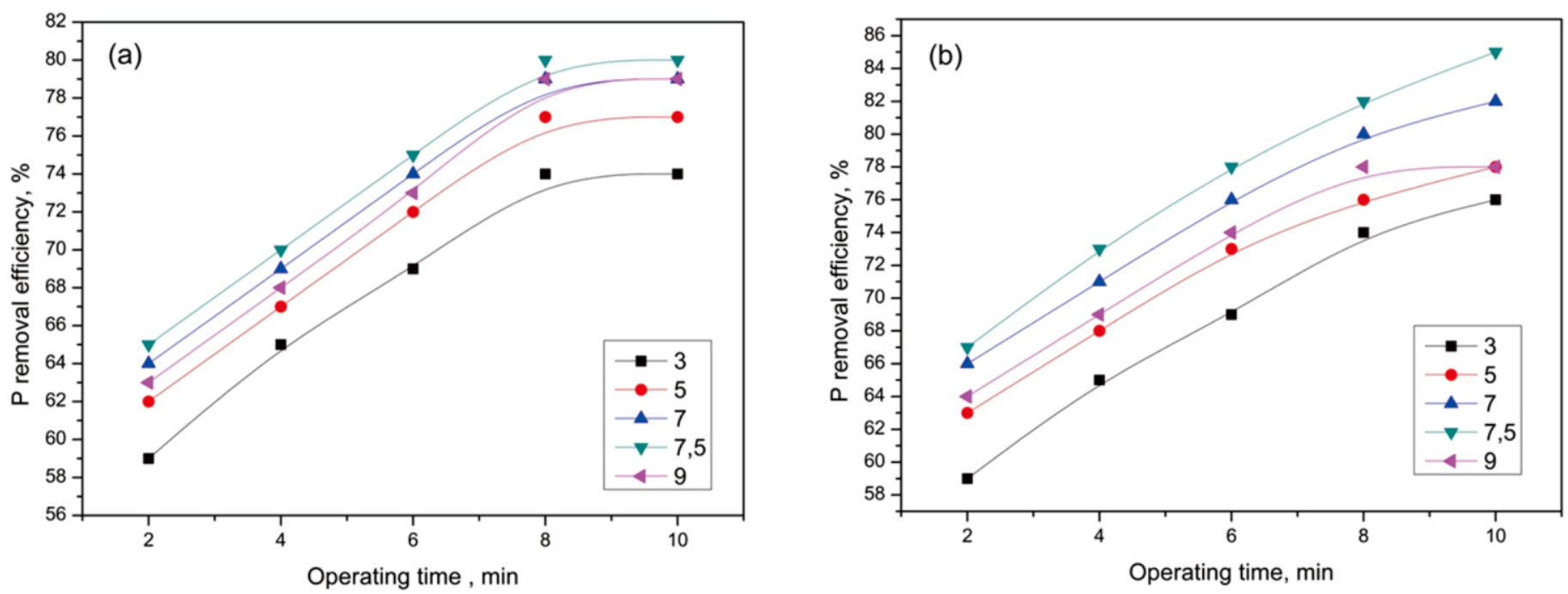

Fig. 3 Effect of initial pH on P removal (a) Iron plate (b) Iron scrap (Current: $1.5 \mathrm{~A}$; packed density $200 \mathrm{~kg} \cdot \mathrm{m}^{-3}$ ).

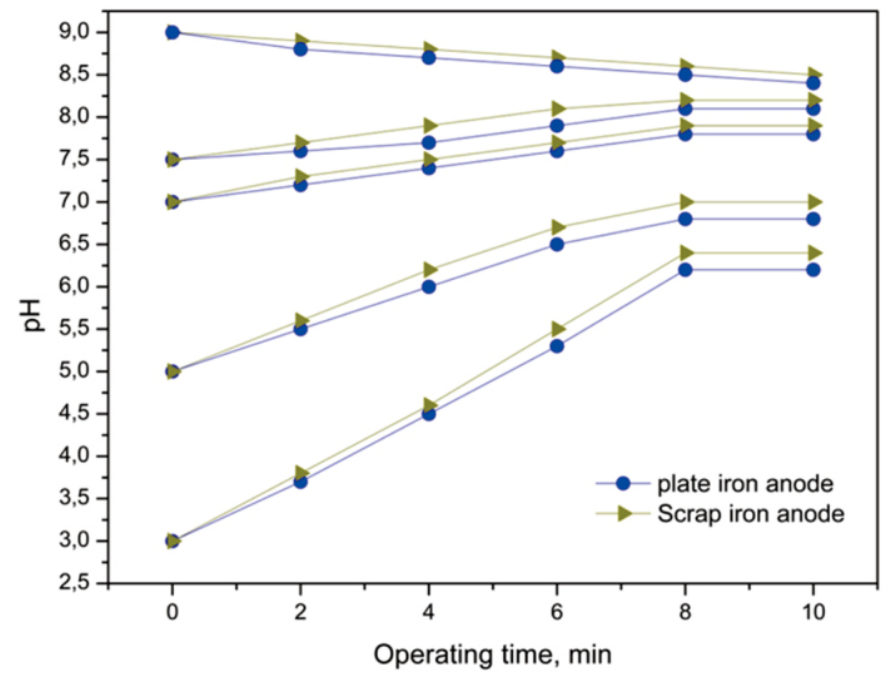

Fig. 4 Variation of initial $\mathrm{pH}$ during electrolysis for plate and scrap iron anode. 
scrap as anode can enhance the removal of $\mathrm{P}$ and COD from urban wastewater and the required current for achieving the maximum COD and $\mathrm{P}$ removals was $2 \mathrm{~A}$. It was also reported that the increase in current led to increase the amount of iron hydroxide available in solution and the coagulant production rate, which improves the removal efficiency. ${ }^{35}$ Moreover, the bubbles generation rate increased with increasing the current that contributes to the improvement of pollutant removal from wastewater by electroflotation process. ${ }^{17}$ The size of bubble decreases with increasing the current and smaller bubbles ensure larger surface area for flocculation that provides enhancement in pollutant removal. ${ }^{36}$ However, very high current values and operating time may negatively affect the EC removal efficiency. This behavior is attributed to the generation of another secondary reaction that could reverse the charge of the colloids and lead to the decrease in removal efficiency.

\subsection{Effect of anode packed density}

The effect of the anode packed density, including the iron scrap anode $\left(200,400,600 \mathrm{~kg} \cdot \mathrm{m}^{-3}\right)$ and iron plate anode $\left(800 \mathrm{~kg} \cdot \mathrm{m}^{-3}\right)$ on COD and P removal from urban wastewater was performed under current of $2 \mathrm{~A}$, and initial $\mathrm{pH}$ of 7.5. As can be seen from Fig. 7(a) and (b), the removal efficiencies of COD and $\mathrm{P}$ increased using both iron scrap and iron plate anode. At $10 \mathrm{~min}$, the increase in iron scrap anode packed density from 200 to $400 \mathrm{~kg} \cdot \mathrm{m}^{-3}$ led to the increase in the removal efficiencies from 88 to $94 \%$ for COD and from 90 to $97 \%$ for P; while a slight decrease in the removal performance was observed when the iron scrap anode packed density was increased to $600 \mathrm{~kg} \cdot \mathrm{m}^{-3}$. In the case of iron plate Fig. 7 (a) and (b) show that $82 \%$ COD and $85 \%$ P removal were obtained at $8 \mathrm{~min}$ and $800 \mathrm{~kg} \cdot \mathrm{m}^{-3}$ of anode density. It is noteworthy that all iron scrap anodes exhibited better performance than the iron plate anodes.

The difference in the removal performance between iron scrap and iron plate anode can be attributed to the differences in the effective surface area of the two type of anodes for generating electroactive $\mathrm{Fe}^{2+}$ and $\mathrm{Fe}^{3+}$ ions (Ardhan et al., 2014). It was previously reported that there is a direct relationship between the removal efficiency of orange II molecule and the electrode area, because for an equal consumption of electrical energy, the distribution of the electroactive species density becomes more effective with increasing the electrode surface area
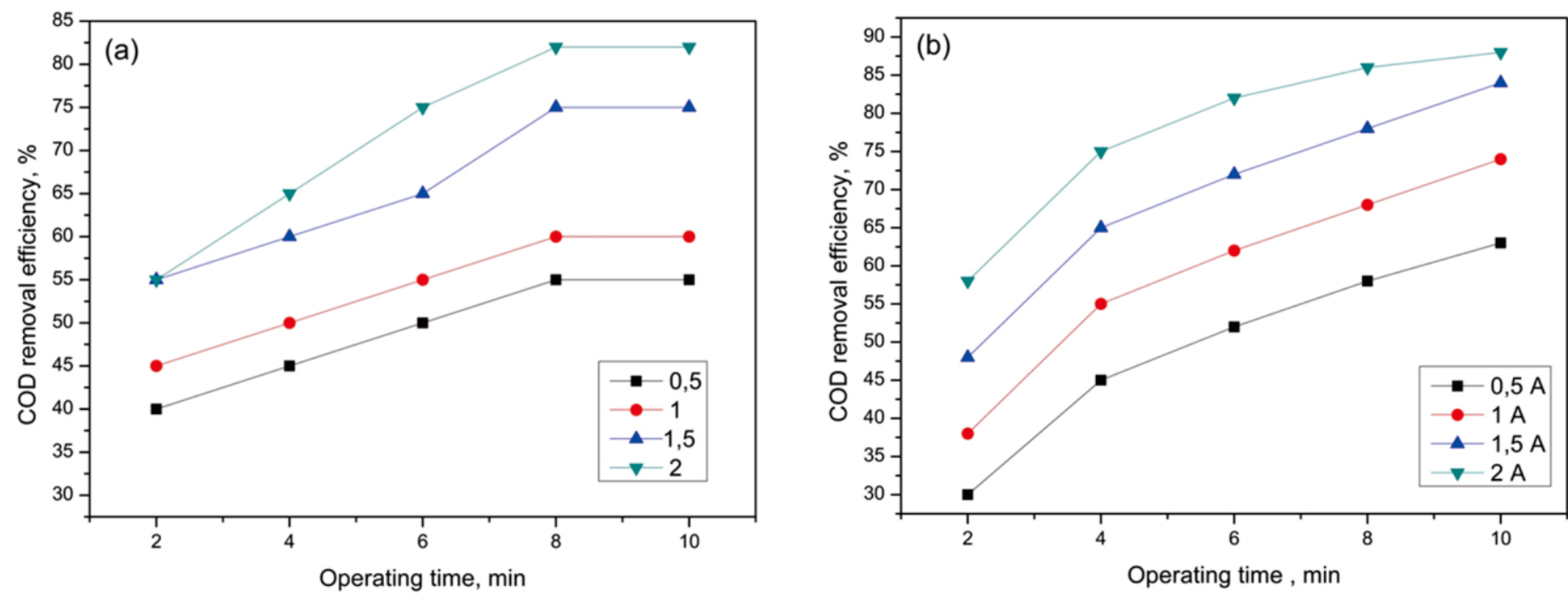

Fig. 5 Effect of current on COD removal (a) Iron plate (b) Iron scrap (initial pH: 7.5; packed density $200 \mathrm{~kg} \cdot \mathrm{m}^{-3}$ ).
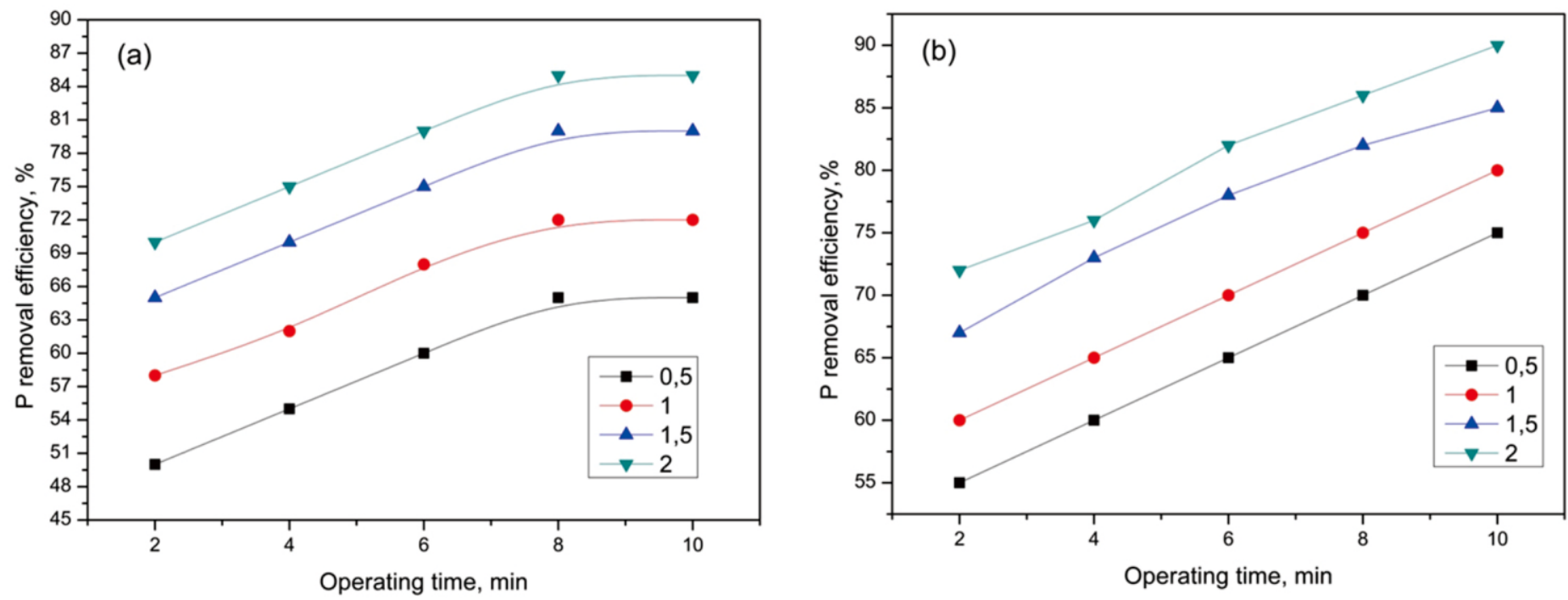

Fig. 6 Effect of current on P removal (a) Iron plate (b) Iron scrap (initial pH: 7.5; packed density $200 \mathrm{~kg} \cdot \mathrm{m}^{-3}$ ). 
(Daneshvar et al., 2007). In this part of study, the difference in the removal efficiencies between the iron scrap anode and iron plate anode can be explained by the high total effective area of packed-bed iron anode $\left(0.084 \mathrm{~m}^{2}\right)$ in comparison with iron plate anode $\left(0.003 \mathrm{~m}^{2}\right)$. Moreover, the difference between internal resistance in the iron scrap and iron plate anode can affect the performance of EC process in term of removal efficiencies. Thus, the higher mass of the iron plate anode in comparison to that of iron scrap anode led to higher resistance, which in turn increased the electric consumption due to the Joule effect (Picard et al., 2000).

\subsection{Energy consumption}

In electrocoagulation process, the energy consumption is considered as a significant parameter because it allows us to evaluate the cost of the process. The energy consumption was calculated in terms of $\mathrm{kWh}$ per $\mathrm{m}^{3}$ of wastewater and $\mathrm{kWh}$ per $\mathrm{g}$ of COD and $\mathrm{P}$ using the following equations:

$$
E C S\left(\mathrm{kWh} \cdot \mathrm{m}^{-3}\right)=\frac{U \times I \times t}{v}
$$

$$
\operatorname{SECS}\left(\mathrm{kWh} \cdot \mathrm{m}^{-1}\right)=\frac{10^{3} \times U \times I \times t}{v \times\left(C_{i}-C_{f}\right)}
$$

where $U$ is the cell voltage (V), $I$ present the applied electrical current (A), $t$ the current time of treatment ( $\mathrm{min}$ ), and $V$ the reactor volume (L). $C_{i}$ and $C_{f}$ represent the initial pollutant concentration and the concentration at time $\mathrm{t}\left(\mathrm{mg} \cdot \mathrm{L}^{-1}\right)$.

Fig. 8 shows the energy consumption (ECS) and specific energy consumption (SECS) of the EC process using different packed densities of iron scrap anode $\left(200-600 \mathrm{~kg} / \mathrm{m}^{-3}\right)$ and a fixed density of anode $(800$ $\mathrm{kg} . \mathrm{m}^{-3}$ ) for plate iron. At a packed density of $200 \mathrm{~kg} \mathrm{~m}^{-3}$, the ECS was $6.62 \mathrm{kWh} \mathrm{m}^{-3}$ and the SECS was calculated as $5.76 \times 10^{-1} \mathrm{kWh} \mathrm{g}^{-1}$ (COD) and $5 \times 10^{-3} \mathrm{kWh} \mathrm{g}^{-1}(\mathrm{P})$. The lowest ECS $\left(5.44 \mathrm{kWh} \mathrm{m}^{-3}\right)$ and SECS $\left(5.12 \times 10^{-1} \mathrm{kWh} \mathrm{g}^{-1}(\mathrm{COD}) 4.3 \times 10^{-3} \mathrm{kWh} \mathrm{g}^{-1}(\mathrm{P})\right)$ values were obtained at a packed density of $400 \mathrm{~kg} \mathrm{~m}^{-3}$. Increasing the packed density to $600 \mathrm{~kg} \mathrm{~m}^{-3}$ led to increase the values of ECS and SECS with $6.4 \mathrm{kWh} \mathrm{m}^{-3}$ and $7.19 \times 10^{-1} \mathrm{kWh} \mathrm{g}(\mathrm{COD})^{-1} 6.4 \times 10-3 \mathrm{kWh} \mathrm{g}(\mathrm{P})^{-1}$, respectively. In the case of plate iron anode, the density of electrode
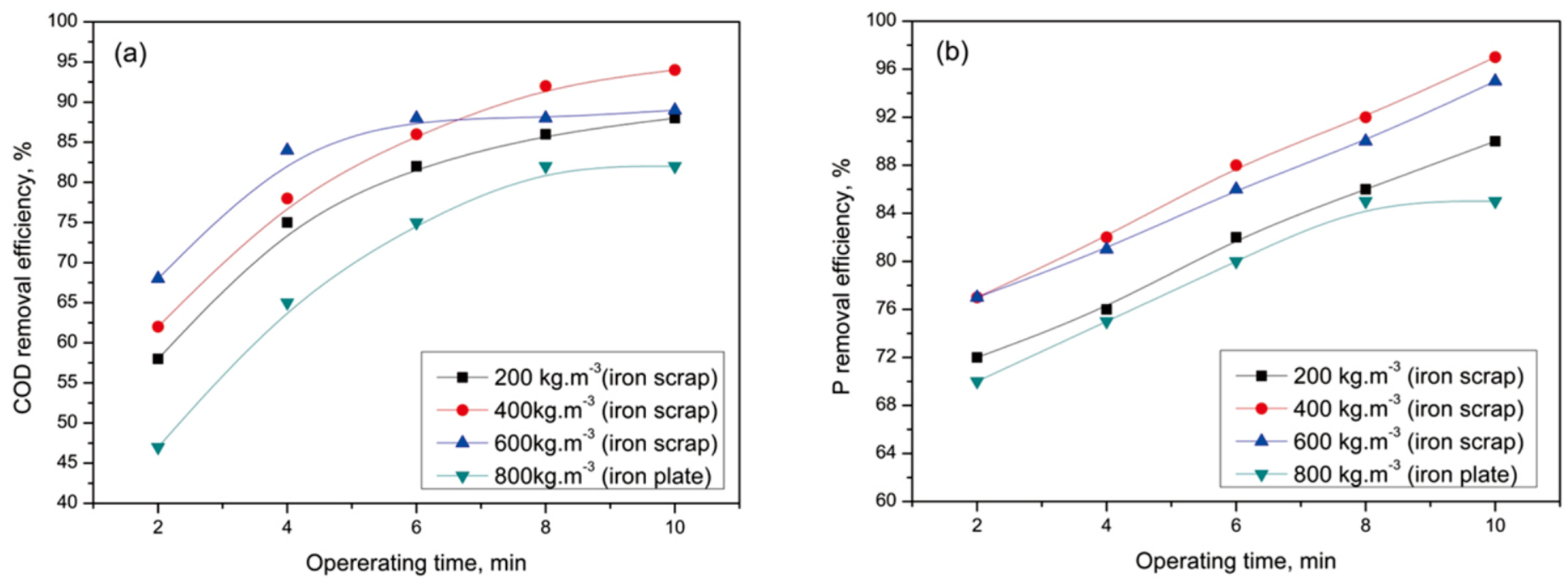

Fig. 7 Effect of packed density on (a) COD removal (b) $\mathrm{P}$ removal (initial $\mathrm{pH}=7.5$; current $=2 \mathrm{~A}$ ).
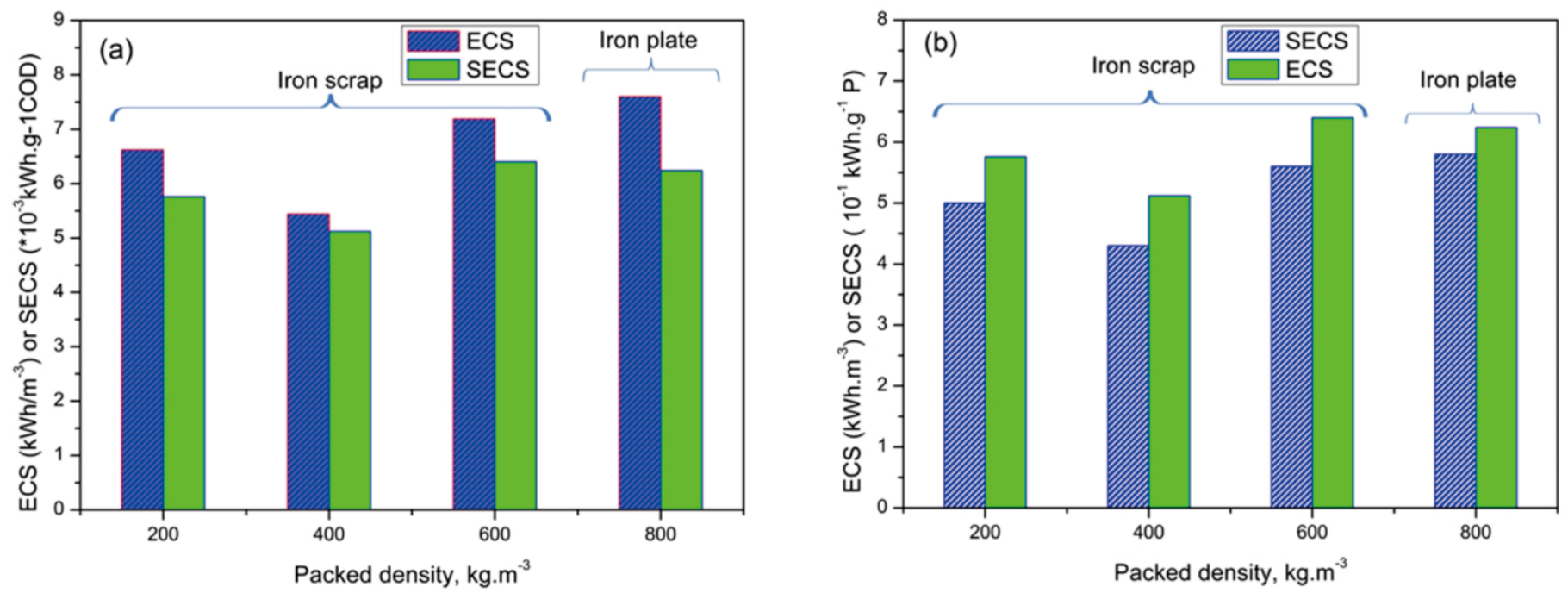

Fig. 8 Effect of packed density on energy consumption (ECS) and specific energy consumption (SECS) for (a) $\mathrm{COD}$ (b) $\mathrm{P}$ (initial pH = 7.5; current $=2 \mathrm{~A}$ ). 
was $800 \mathrm{~kg} \mathrm{~m}^{-3}$ and the values of ECS and SECS were found to be 6.24 $\mathrm{kWh} \mathrm{m}^{-3}$ and $7.6 \mathrm{kWh} \mathrm{g}^{-1}$ (COD) and $5.8 \mathrm{kWh} \mathrm{g}^{-1}(\mathrm{P})$.

\section{Characterization of EC by-products generated by Fe scrap anode}

4.1 Morphology and chemical composition of generated sludge

To evaluate the structural features and elemental composition of the sludge formed by the EC process using iron scrap electrodes, SEM images and elemental composition of the generated sludge are shown in Fig. 9. The SEM image did not show any crystalline shape on sludge surface, which indicates the presence of mostly amorphous or ultrafine particular structure at $\mu \mathrm{m}$ size. EDX spectra of sludge formed by $\mathrm{Fe}$ scrap electrodes confirmed the presence of the removed phosphorous by
0.05 at. $\%$ from the solution. The peaks correspond to oxygen (30.59 at.\%) and carbon (38.50at.\%) confirming the presence of organic compounds in the wastewater that were adsorbed on the surface of the colloids. The other peaks indicate that $\mathrm{Na}$ (2.08 at.\%), Fe (24.50 at.\%), $\mathrm{S}$ (1.42 at.\%), $\mathrm{Cl}(1.24$ at.\%) and heavy metals are also presented in the sludge formed during EC process with scrap Fe anode.

\subsection{Structure of generated sludge}

The X-ray diffraction result of sludge generated using Fe scrap electrodes is shown in Fig. 10. The $2 \theta$ scans were recorded from $5^{\circ}$ to $90^{\circ}$. The spectrum of the analyzed by-products does not show any sludge structure with no intense characteristic diffraction peaks over a wide range of $2 \theta\left(15-80^{\circ}\right)$, confirming poor arrangement of particles with ferric sludge. ${ }^{37}$
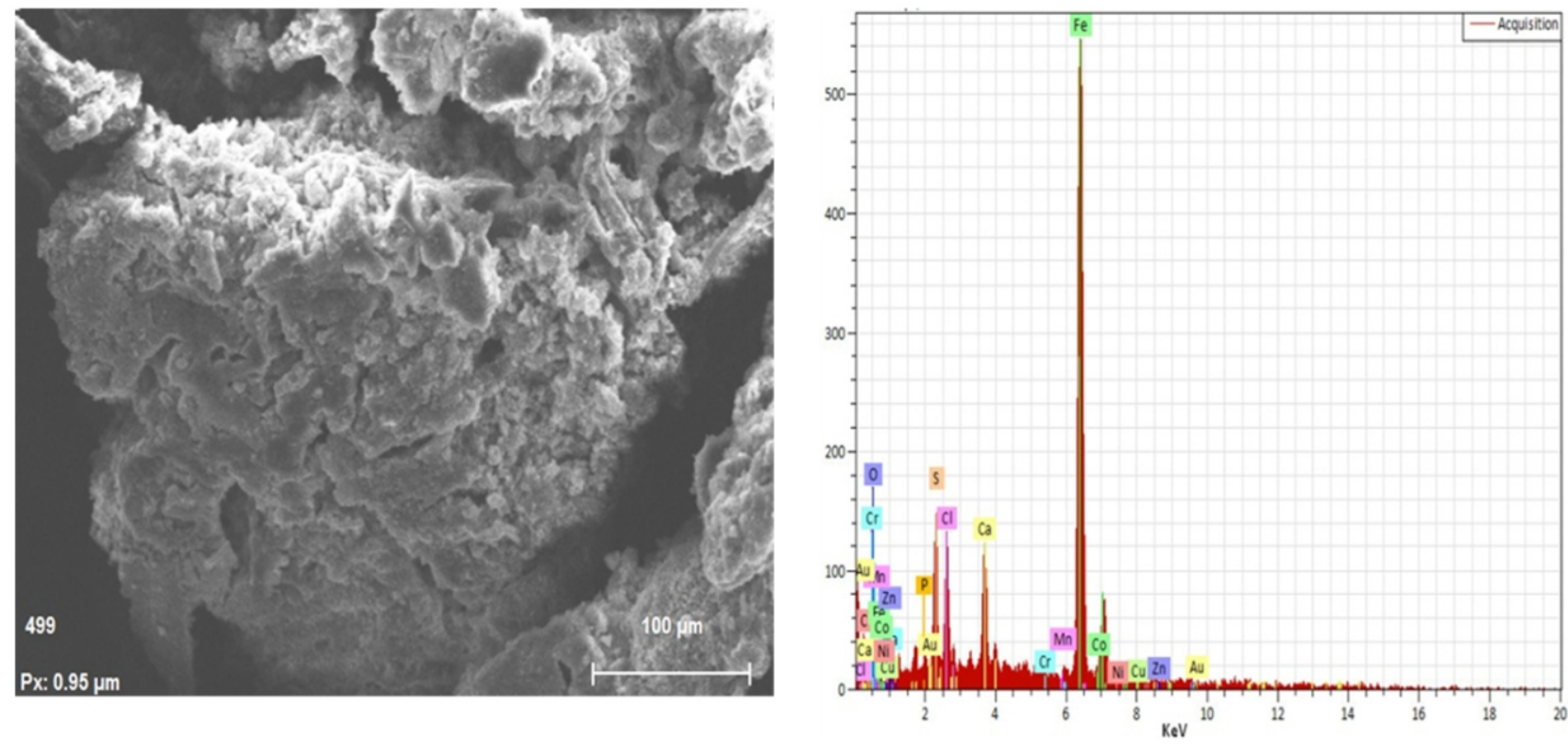

Fig. 9 SEM/EDX of sludge produced using Fe scrap anode.

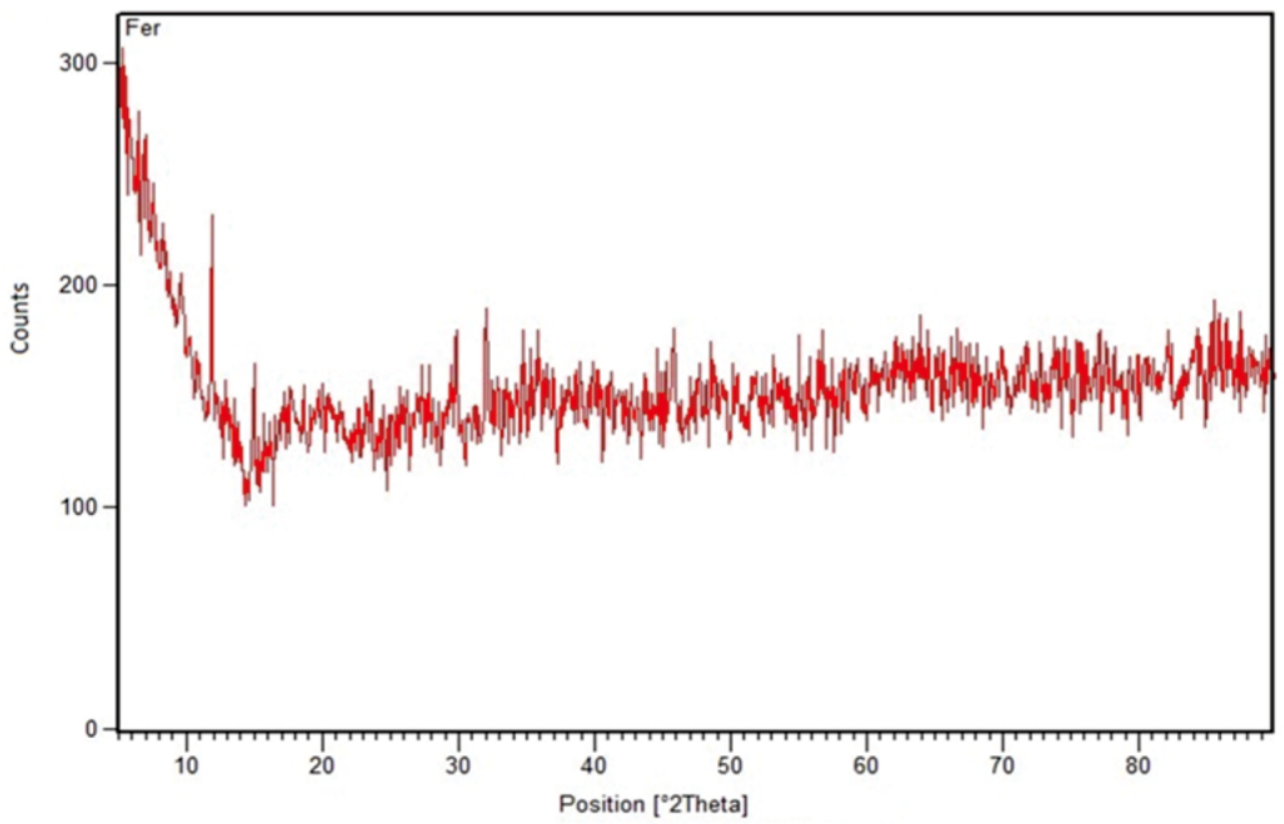

Fig. $10 \mathrm{XRD}$ of sludge produced using Fe scrap anode. 


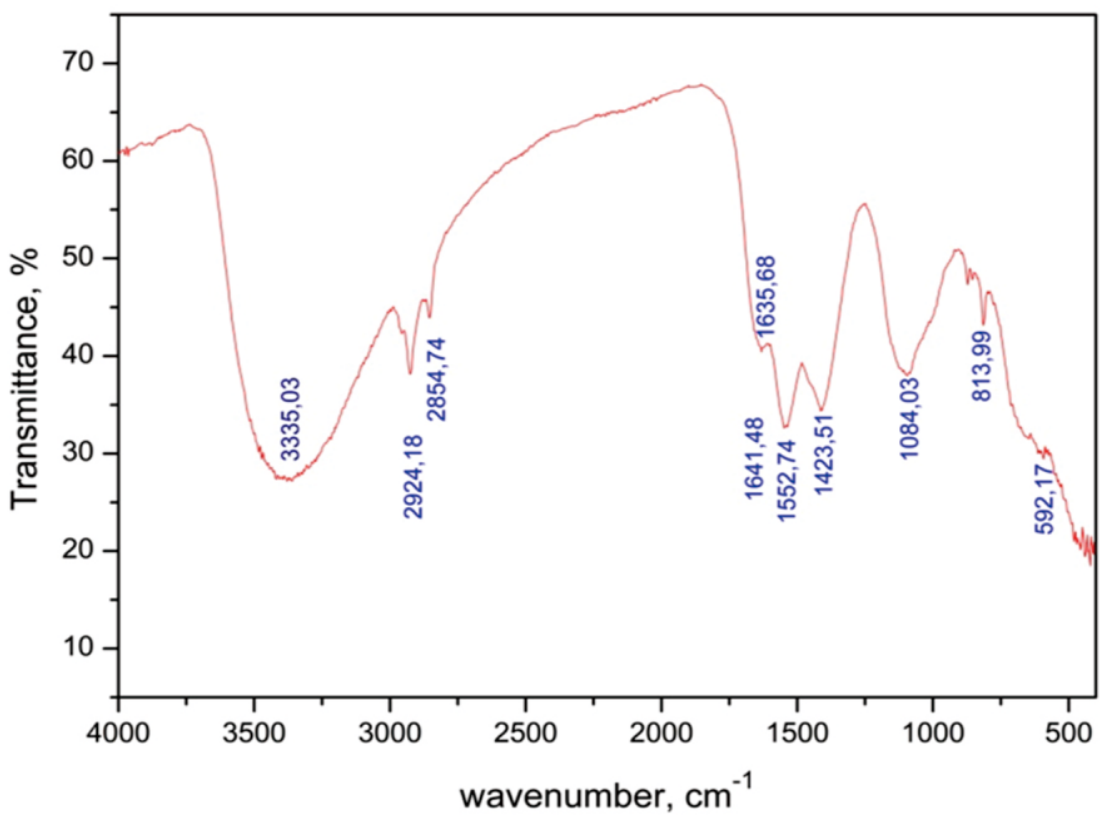

Fig. 11 FTIR analysis of EC by-products using Fe scrap anode.

\subsection{Identification of functional groups in generated sludge}

The infrared spectrum of the sludge also analyzed at wave numbers between 500 to $4000 \mathrm{~cm}^{-1}$ is depicted in Fig. 11. The strong peak at $3335 \mathrm{~cm}^{-1}$ was attributed to stretching vibration of $-\mathrm{OH}$ and $\mathrm{H}-\mathrm{O}-\mathrm{H}$ bending modes of free water, hydroxyl bending and $\mathrm{OH}$ water bending vibration or overtones of hydroxyl bending around $1636 \mathrm{~cm}^{-1}$. Peaks at 2854 and $2924 \mathrm{~cm}^{-1}$ are corresponding to $\mathrm{C}-\mathrm{H}$ stretching mode of saturated C-C bonds. The peak at $813 \mathrm{~cm}^{-1}$ and $1084 \mathrm{~cm}^{-1}$ could be attributed to the $\mathrm{Fe}(\mathrm{III})$ solid which was identified as lepidocrocite phase of $\alpha-\mathrm{FeOOH}$ and $\mathrm{Fe}_{2} \mathrm{O}_{3}$ of iron oxyhydroxides. ${ }^{38}$ The peak at 592 $\mathrm{cm}^{-1}$ revealed the presence of Magnetite $\left(\mathrm{Fe}_{3} \mathrm{O}_{4}\right)$. The peak located at 1084 is attributed to $\mathrm{P}-\mathrm{O}$ vibration of adsorbed phosphate or Fe-O bond stretching confirming that phosphate was successfully adsorbed on hydroxide metal.

These analyses of the generated EC by-products revealed the presence of phosphate $(\mathrm{P})$, carbon $(\mathrm{C})$ and oxygen $(\mathrm{O})$, which indicates that such pollutants were adsorbed on the surface of iron hydroxides and oxyhydroxides, where the removals of $\mathrm{P}$ and COD were successfully removed from urban wastewater. Finally, we could conclude that the higher treatment efficiency obtained from the developed EC treatment process can be explained by the higher specific surface area of the Fe scrap that induces the production of more electrogenerated coagulants than the Fe plate, which is dependent strongly here on the current, operating time and packed density.

\section{Conclusion}

A low-cost EC process was developed here by using iron scrap as the anode to improve the removal efficiencies of COD and $\mathrm{P}$ from real urban wastewater. The maximum removal efficiencies of $\mathrm{P}$ and COD at optimum conditions were found to be $97 \%$ and $94 \%$, respectively. It was also found here the energy consumption of the urban wastewater was reduced from $7.6 \times 10^{-3}$ to $5.4 \times 10^{-3} \mathrm{kWh} / \mathrm{g}$ COD and from $5.8 \times 10^{-1}$ to $4.3 \times 10^{-1} \mathrm{kWh} / \mathrm{g}$ P when switching from conventional to developed $\mathrm{EC}$ treatment process. The higher treatment efficiency obtained from the developed EC treatment process can be explained by the higher surface area of the Fe scrap for the distribution of the electroactive species, that induces the production of more electrogenerated coagulants than the $\mathrm{Fe}$ plate, which is dependent strongly here to the current, operating time and packed density. In order to better understand the removal mechanism of COD and P of the developed EC process, the generated by-products were characterized using SEM/EDX, XRD and FTIR analyses. These analyses confirmed the presence of $\mathrm{P}, \mathrm{C}$ and $\mathrm{O}$ as the main components of the sludge, which indicates that such pollutants are successfully removed from urban wastewater. Regarding the performance of this developed EC using Fe scrap as the anode, we can assume that the developed EC technique can open new doorway to be used effectively in order to remove other pollutants from various types of wastewaters, which could be more promising than conventional electrocoagulation using plate electrode.

\section{Acknowledgments}

The research group would like to acknowledge the Center of Innovation and Development of Tangier, Morocco and also Dr. A. Aouaaram from ONEE (Al Hoceima) for his technical support. Dr. A. El Kasmi is so grateful to the financial support of Chinese Academy of Sciences for senior international scientists within the framework of PIFI program (Grant No. 2017PE0009).

\section{References}

1. Ş. İrdemez, N. Demircioğlu, Y.Ş. Yıldız and Z. Bingül, Sep. Purif. Technol., 2006, 52, 218-223.

2. S. R. Carpenter, N. F. Caraco, D. L. Correll, R. W. Howarth, A. N. Sharpley and V. H. Smith, Ecol. Appl., 1998, 8, 559-568.

3. S. Suarez, J. M. Lema and F. Omil, Bioresource Technol., 2009, 100, 2138 2146

4. M. Chenna, R. Chemlal, N. Drouiche, K. Messaoudi and H. Lounici, Desalin Water Treat., 2016, 57, 27003-27014.

5. E. J. Rosenfeldt, P. J. Chen, S. Kullman and K. G. Linden, Sci. Total Environ., 2007, 377, 105-113.

6. T. M. LaPara and J. E. Alleman, Water Res., 1999, 33, 895-908.

7. S. Rajput, C. U. Pittman and D. Mohan, J. Colloid Interf. Sci., 2016, 468, 334-346.

8. S. J. T. Pollard, G. D. Fowler, C. J. Sollars and R. Perry, Sci. Total Environ., 1992, 116, 31-52.

9. S. Wang and H. Wu, J. Hazard. Mater, 2006, 136, 482-501. 
10. A. Pala and E. Tokat, Water Res., 2002, 36, 2920-2925.

11. F. Ghanbari and M. Moradi, J. Environ. Chem. Eng., 2015, 3, 499-506.

12. S. Aoudj, A. Khelifa, N. Drouiche, R. Belkada and D. Miroud, Chem. Eng. J., 2015, 267, 153-162.

13. H. D. Bassala, G. K. Dedzo, C. B. N. Bememba, P. M. T. Seumo, J. D. Dazie, C. P. Nanseu-Njiki and E. Ngameni, Process Saf. Environ., 2017, 111, 122-127.

14. E. Lacasa, P. Cañizares, C. Sáez, F. J. Fernández and M. A. Rodrigo, Chem. Eng. J., 2011, 171, 1012-1017.

15. M. A. Sari and S. Chellam, J. Colloid Interf. Scie., 2015, 458, 103-111.

16. D. Valero, J. M. Ortiz, V. García, E. Expósito, V. Montiel and A. Aldaz, Chemosphere, 2011, 84, 1290-1295.

17. U. T. Un, A. S. Koparal and U. B. Ogutveren, J. Environ. Manage., 2009, 90, 428-433.

18. J. Feng, Y. Sun, Z. Zheng, J. Zhang, L. I. Shu and Y. Tian, J. Environ. Sci., 2007, 19, 1409-1415.

19. F. Janpoor, A. Torabian and V. Khatibikamal, J. Chem. Technol. Biot., 2011, 86, 1113-1120.

20. N. Boudjema, N. Drouiche, N. Abdi, H. Grib, H. Lounici, A. Pauss and N. Mameri, J. Taiwan Inst. Chem. Eng., 2014, 45, 1564-1570.

21. M. Elazzouzi, A. El Kasmi, K. Haboubi and M. S. Elyoubi, Process Saf. Environ., 2018, 116, 506-515.

22. M. Elazzouzi, K. Haboubi and M. S. Elyoubi, Chem. Eng. Res. Des., 2017, 117, 614-626.

23. N. Daneshvar, A. R. Khataee, A. R. Amani Ghadim and M. H. Rasoulifard, J. Hazard. Mater., 2007, 148, 566-572.

24. E. S. Z. El-Ashtoukhy and N. K. Amin, J. Hazard. Mater., 2010, 179, 113119.

25. P. Canizares, F. Martínez, C. Jiménez, C. Sáez and M. A. Rodrigo, J. Hazard.
Mater., 2008, 151, 44-51.

26. I. Zongo, A. H. Maiga, J. Wéthé, G. Valentin, J. P. Leclerc, G. Paternotte and F. Lapicque, J. Hazard. Mater., 2009, 169, 70-76.

27. R. Mores, H. Treichel, C. A. Zakrzevski, A. Kunz, J. Steffens and R. M. Dallago, Sep. Purif. Technol., 2016, 171, 112-117.

28. X. Ye, J. Zhang, Y. Zhang, Y. Lv, R. Dou, S. Wen, L. Li, Y. Chen and Y. Hu, Chemosphere, 2016, 164, 304-313.

29. N. Ardhan, E. J. Moore and C. Phalakornkule, Chem. Eng. J., 2014, 253, 448-455.

30. H. T. Arthur, Standard Methods for the Examination of Water and Wastewater, (2005).

31. M. Carmona, M. Khemis, J. P. Leclerc and F. Lapicque, Chem. Eng. Sci., 2006, 61, 1237-1246.

32. M. Y. A. Mollah, R. Schennach, J. R. Parga and D. L. Cocke, J. Hazard. Mater., 2001, 84, 29-41.

33. N. Adhoum and L. Monser, Chem. Eng. Process., 2004, 43, 1281-1287.

34. A. Aleboyeh, N. Daneshvar and M. B. Kasiri, Chem. Eng. Process., 2008, 47, 827-832.

35. M. Kobya, E. Gengec and E. Demirbas, Chem. Eng. Process., 2016, 101, $87-$ 100.

36. C. An, G. Huang, Y. Yao and S. Zhao, Sci. Total Environ., 2017, 579, $537-$ 556.

37. K. K. Garg, B. Prasad, J. Environ. Chem. Eng., 2016, 4, 178-190.

38. J. A. G. Gomes, P. Daida, M. Kesmez, M. Weir, H. Moreno, J. R. Parga, G. Irwin, H. McWhinney, T. Grady, E. Peterson and D. L. Cocke, J. Hazard. Mater., 2007, 139, 220-231.

Publisher's Note Engineered Science Publisher remains neutral with regard to jurisdictional claims in published maps and institutional affiliations. 